Among the older nestlines, Mountain Bluebirds appear to have reached the saturation point in nestings; notable among these are the SOUTHEAST LINE, run by Ed Robinson, and the SOUTHWEST LINE of Art Giles, as well as the TRANSCANADA LINE.

The common House Sparrow has now assumed the title of chief enemy of the bluebirds. We have previously noted in the Blue Jay for December, 1970, how this pest had taken over the BRANDON-GLADSTONE-AUSTIN LINE. The same calamity overtook the NORTHWEST LINE this year; where a day's banding last year yielded 265 bluebirds on this route, the total for a day this year was 38 banded. Sparrows had taken over about two-thirds of the nests, cornering and killing the adult bluebirds when they got in the way. Little can be done to combat these tough vandals, and the only solution seems to be to move the entire nestline to a new area.

Lack of time this season limited the banding of bluebirds to only 1,684 , but this does bring our four-year total to over 10,000 bluebirds banded. Our estimated nestings this season follow:

$\begin{array}{lrlrlr}\text { Mountain Bluebirds } & 825 & \text { Tree Swallows } & 2450 & \text { Starlings } & 10 \\ \text { Eastern Bluebirds } & 150 & \text { House Sparrows } & 225 & \text { Deer Mice } & 90 \\ \text { Hybrid Bluebird } & 1 & \text { House Wrens } & 35 & \text { Red Squirrels } & 10\end{array}$

\title{
1972 ALBERTA RAPTOR BANDING REPORT
}

\author{
by CHRIS S. REES*
}

1972 proved to be a highly successful year for the group of Albertan raptor banders with a final count of 1,399 birds of 22 species banded. This brings the total raptors banded by the group to approximately 3,840 since 1967 . The banders involved were: Harry Armbruster, Rod Burns, John and Nial Campbell, Tom Donald, Richard, Ken, Kip and Kelly Fyfe, Ron Gallant, Bob Gehlert, Michael J. Hampson, Pat Harris, Keith Hodson, Wolfe Hoffmann, Mike Johnson, Edgar T. Jones, Lynne and Brian Kemper, Brian Nicolai, Chris Rees, Tom Russell, Dave Schowalter, Rich Svrcek, Ken Trann, Phil Treffery and Bruce Treichel.

Early in the winter of 1971-72 several Gyrfalcons were sighted. Snowy Owls were common but difficult to catch in the later part of the winter. These owls are again common this winter (1972-1973) and perhaps a little more responsive to trapping technique. Sparrow Hawks were reasonably numerous on the spring migration but proved to be so difficult to trap that several banders became discouraged and went on to band other species. This resulted in a drastic drop in the number of Sparrow Hawks banded as compared to the 1971 count. Both Long-eared and Short-eared owls were common this summer. Two large concentrations of Short-eared Owls could be noted, one north and one south of the city of Edmonton. Several members of the group worked very hard in the area south of the city finding 18 to 20 nests. Several of the nests found north of the city were destroyed either by farming operations or by predation. Long-eared Owls could be found nesting in nearly every willow and poplar tangle and others were heard hooting from heavier woods earlier in the spring. These large concentrations of eared-owls probably indicate a high population of mice and voles which in turn could explain the poor success in Sparrow Hawk trapping.

The highlight of the fall had to be the tremendous movement of Goshawks into and through the district. The use of the "swede" trap proved to be very effective

*No. 2 - 13027 - 83rd St., Edmonton, Alberta. 
against these large accipters. Two bonuses caught in the swede traps set for Goshawks were a Boreal Owl and a Hawk Owl. As of this writing (January 18, 1973), at least one other Hawk Owl and two Great Grey Owls have been spotted within 30 miles of the city. It will be interesting to see if later in the winter boreal raptors move out of the more northerly forest.

Two of the more interesting band returns that have been received so far involve Sparrow Hawks. An adult banded south of Edmonton on April 23, 1967, was retrapped and released in the same area on July 15, 1971. This particular bird, therefore, had a life span in the wild state of at least 5 years and indicates a strong tendency to return to a given area year after year. The other record is for an adult Sparrow Hawk banded at Fort Saskatchewan on July 24, 1970, and recovered at Munroe, Michigan, on October 22, 1971, indicating more easterly movement than would be expected. Unfortunately, the group has received a total of only 42 returns to date. The general feeling is that the total number of birds is now great enough that we should receive a larger number of returns in the future.

\section{ALBERTA RAPTOR BANDING - 1972 Banders* and Number Banded}

\begin{tabular}{|c|c|c|c|c|c|c|c|c|c|c|c|}
\hline Species & W. $H$ & R.G. & $\begin{array}{l}\text { R.F. } \\
\text { Alta }\end{array}$ & $\begin{array}{l}\text { R.F. } \\
\text { Non }\end{array}$ & $K . T$. & R.B. & E.J. & M.H. & B.G & C.R. & Total \\
\hline Goshawk & & & 6 & & & 1 & 2 & 5 & 14 & 9 & 37 \\
\hline Sharp-shinned & & & & & & & & & & & \\
\hline Hawk & & & & & & & 3 & & 1 & 5 & \\
\hline Cooper's Hawk & & & 3 & & 8 & & 3 & 1 & 3 & & 1 \\
\hline Red-tailed & & & & & & & & & & & \\
\hline Hawk & & & 1 & & 9 & 91 & 25 & & & 2 & 128 \\
\hline Broad-winged & & & & & & & & & & & \\
\hline Hawk & & 1 & & & 4 & 10 & & & 5 & & 20 \\
\hline $\begin{array}{l}\text { Swainson's } \\
\text { Hawk }\end{array}$ & & & & & & & & & & & \\
\hline $\begin{array}{l}\text { Hawk } \\
\text { Ferruginous }\end{array}$ & & & 68 & & 10 & 34 & 14 & & & 2 & $12 \varepsilon$ \\
\hline Hawk & & & 217 & 18 & & & 1 & & & & 236 \\
\hline Golden Eagle & & & 21 & 11 & & & & & & & . \\
\hline Marsh Hawk & & & & & 12 & 8 & 8 & & & 10 & 38 \\
\hline Prairie Falcon & & & 215 & 32 & & & & & & & 247 \\
\hline Pigeon Hawk & & & 79 & 21 & & 4 & & & & & 104 \\
\hline Sparrow Hawk & & 5 & & & 11 & 32 & & & 9 & 5 & 62 \\
\hline Gyrfalcon & & & & 10 & & & & & & & 10 \\
\hline Great Horned & & & & & & & & & & & \\
\hline Owl & & 3 & & & 25 & & 3 & 2 & 3 & 28 & 64 \\
\hline Snowy Owl & 17 & 3 & & & 4 & & 2 & 1 & 2 & 5 & 34 \\
\hline Hawk Owl & & & & & 1 & & & & 8 & 2 & 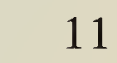 \\
\hline Great Gray Owl & & & & & & & 10 & & 4 & & 14 \\
\hline Long-eared Owl & & 3 & & & 47 & 8 & & & 17 & 34 & 109 \\
\hline Short-eared Owl & & 4 & & & 76 & 7 & & & 7 & & 94 \\
\hline Boreal Owl & & & & & & & & & & 1 & 2 \\
\hline Saw-whet Owl & & & & & & & 1 & & & 2 & \\
\hline
\end{tabular}

$\begin{array}{llllllllllll}\text { TOTALS } & 17 & 19 & 610 & 92 & 207 & 195 & 72 & 9 & 73 & 105 & 1399\end{array}$

*W.H. - Wolfe Hoffman; R.G. - Ron Gallant; R.F. Alta. - Richard Fyfe, Harry Armbuster and Canadian Wildlife Service summer students and volunteer help; R.F. Non - includes Quebec, Yukon, N.W.T. and Saskatchewan records; K.T. - Ken Trann, Brian Nicolai, Rick Svcrek ; R.B. - Rod Burns; E.J. - E. T. Jones; M.H. - M. J. Hampson; B.G. - Bob Gehlert; C.R. - Chris Rees, Bruce Treichel. 